REGULAR ARTICLE

\title{
RAINFALL FLUCTUATIONS AND ECONOMIC GROWTH: EVIDENCE FROM SENEGAL
}

\author{
François Joseph CABRAL
}

\begin{abstract}
Address:
Labouratoire de recherches sur les institutions et la croissance (LINC), Consortium pour la Recherche Economique et Sociale (CRES), Université Cheikh Anta Diop de Dakar (UCAD). E-mail: joecabral7@gmail.com,
\end{abstract}

\begin{abstract}
In this paper, we simulate and evaluate the impact of extreme rainfall events on various sectors in the economy; factors of production remuneration and economic growth in Senegal. A dynamic general equilibrium model is developed which includes an index linking rainfall fluctuations to total productivity factor (TPF) and factor market. Based on rainfall trends during the past three decades, we run simulations to assess the effects of rainfall values on GDP growth. The results show that extreme events in rainfall pattern deeply affect GDP growth in Senegal; sharp drops in rainfall lead to declining GDP and periods of abundant rainfalls are marked by better performance in term of GDP. However, rainfall drops lead to losses in GDP growth in comparison to gains in GDP growth due to rainfall surplus.
\end{abstract}

Keywords: climate change, rainfall, agriculture, economic growth, CGE JEL: Q1, O13, I3, C6

\section{INTRODUCTION}

Already in the 1990s, global warming represented a major societal concern. This well-known phenomenon is nowadays becoming a more tangible threat. According to the GEIC predictions (2007), the number of people in Africa who might be facing water shortages by 2020 is estimated between 75 to 250 million. Consequently, the loss of agricultural land through desertification may also be substantial. In addition to this, favourable periods for cultivation will be shorter. In some countries where agriculture is heavily dependent on rainfall there will be frequent drought and lower crop yields. Sub-Saharan Africa faces the largest food-deficit and water-scarcity challenges. For many small farms in the semi-arid tropics, it is simply not worth investing in fertilizers (and other external inputs) so long as the risks for crop failure and yield reductions remain a reality. These high risks are associated with periodic water scarcity during the growing season. Hence, economic growth can heavily be dependent on rainfall. Since agriculture is directly linked to other sectors of the economy, reduced agricultural yields are expected to affect industries and services through inter-sectoral linkages.

Moreover, after the latest global financial crisis, many predictions pointed out relative optimism about the future trend of growth in sub-Saharan African economies, as compared to the rest of the world (World Bank, 2012). However, this predicted trend highly depends on several endogenous factors. From recent literature on endogenous growth, human capital, public expenditures, quality of institutions, macroeconomic framework are quite crucial (Acemoglu and al., 2002, Barro and al., 1995, Aghion and al., 1992, Mankiw and al., 1992). In addition, growth depends on some exogenous factors. Landlocked geography and tropical climates seem to be highly prominent for many African nations (Bloom and Sachs, 1998). As observed since 1960, rainfall has been on a general decline in Africa (Nicholson, 1994; Barrios and al., 2010). For many African countries, agriculture is an important sector and it is mainly rain-fed, meaning that, decreasing rainfalls might have had severe consequences on economic growth (Nicholson, 1994; Collier and Gunning, 1999; O'Connell and NDulu, 2000; Bloom and Sachs, 1998).

The effects of climate are increasingly visible and a growing number of studies are being conducted to produce more robust empirical evidence about its effects on economic growth. Using a new cross-country panel climatic data set in an empirical economic growth framework, Barrios and al. $(2008,2010)$ have examined the role of rainfall trends in poor growth performance of sub-Saharan African nations relatively to other developing countries. The results show that the detrimental changes in climate since the 1960s can account for a substantial portion of the gap in agricultural production between SSA and the rest of the developing world. This results is close to the one established by World Bank (1991) which found that decline in per capita food consumption in Africa appears to be more pronounced during the major drought episodes observed from 1968 to 1973 and from 1981 to 1984 . This suggests possible impacts of drought on food productivity (Tarhule, 2007). Benson (1994) showed also that major drought that occurred in 1992 over much of southern Africa led to a decline of 9\%, 8\% and 3\% in GDP for Zambia, Zimbabwe and South Africa, respectively. Recently, literature has been enriched by several 
environmental studies based on the general equilibrium model (CGE). Several studies have used this framework to assess the costs attributable to climate change, in particular, the cost in terms of production shortfalls in the U.S (McDougall, 1997, Stuart and al., 1997, Parry and al., 1990, Rosenberg, 1993).

The effects of rainfall fluctuation on the poor growth performance of sub-Saharan African economies is weakly explored as an area of research. Even if they are assessed, economy wide and feed-back effects of rainfall shocks are not analysed. In Senegal, the main activity of the poor relies on rain-fed agriculture.

Most of studies dealing with effects of rainfall on economic growth rely on partial equilibrium framework (Nicholson, 1994; Bloom and Sachs, 1998; Collier and Gunning, 1999; O'Connell and NDulu, 2000; Barrios and al., 2010). In this paper, we try to analyse the effects of rainfall on economic growth through a general computable equilibrium (CGE) framework.

Several CGE models have been developed to assess various issues related to Senegalese economy (Dissou, 2000; Dumont and al., 2001; Deculuwe and al. 2001; Diagne and al., 2003; Boccanfuso and al., 2005; Cabral, 2005; Fofana and al., 2005; Boccanf uso and al., 2007). However, none of them have attempted to analyse the effects of rainfall fluctuations on economic growth. In this paper, our main objective is to assess the impact of rainfall shocks on economic growth in Senegal, using a recursive dynamic CGE model. With such a framework, one can take into account the feed-back and economy wide effects of shocks which pass through TFP, factor markets, input-output channel and resource reallocation process (Decaluwé and al., 2001). In a sahelian economy like Senegal, extreme events in rainfall pattern use to induce wide economic effects and also feed-back effects due to intersectoral links between.

In the sections that follow, we conduct a descriptive analysis of the changes in economic growth in relation to rainfalls (Section 1).Section 2 explains the methodology of our research. Section 3 displays the results. Finally, the paper concludes and provides some implications for policy and further research.

\section{Background}

In Senegal, even if more than half of active population is located in rural area, the contribution of agriculture in the GDP is relatively weak and is decreasing.

From 1980-2010, the share of agriculture in overall GDP in Senegal has varied between 25 and 14 percent (Figure 1). During the recent global economic crisis, the contribution of agriculture to GDP has declined. However a policy response to cereal shocks have been set in, place so as to boost agricultural sector.

Hence, the impact of rainfall on the economy is not too obvious. As in several sub-Saharan countries, the lead crops are rain-fed. Although the country has a considerable potential to expand irrigation to about 350,000 hectares, only $4 \%$ of irrigable land is currently irrigated, and half of it is located in the Senegal River valley. At least $80 \%$ of the cultivated areas which are mainly devoted to millet and groundnuts cultivation are rainwater dependent. Since the country is largely dependent on rain-fed agriculture, the changes observed in agricultural yield are somehow associated with erratic rainfall patterns.

Figure 1: Contribution of Agricultural Sector to total GDP, 1980-2010 (in \%)

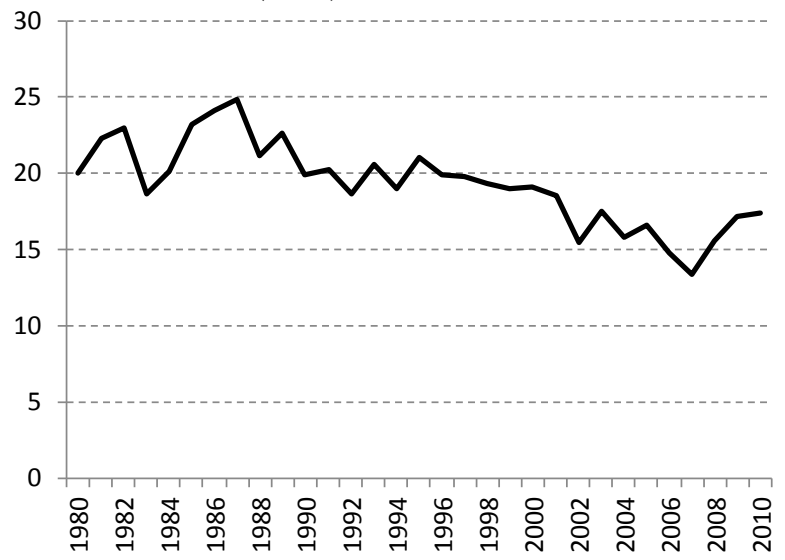

Source: World Bank (2012b)

If productivity in the rice sector has nearly doubled in 30 years due to the expansion of irrigated land for rice production, for the two other major crops groundnut and millet it respectively increased by $14 \%$ and $17 \%$ over the same period. Even if those gaps in crop yields can be attributable to several factors (agricultural policies, real exchange rates, trends in external markets, etc.), irrigation, and access to water seems to be the main factors that explain the performance of yield pattern of rice and other main crops (groundnut and millet).

Figure 2: Rainfall fluctuation in mm, 1970-1999

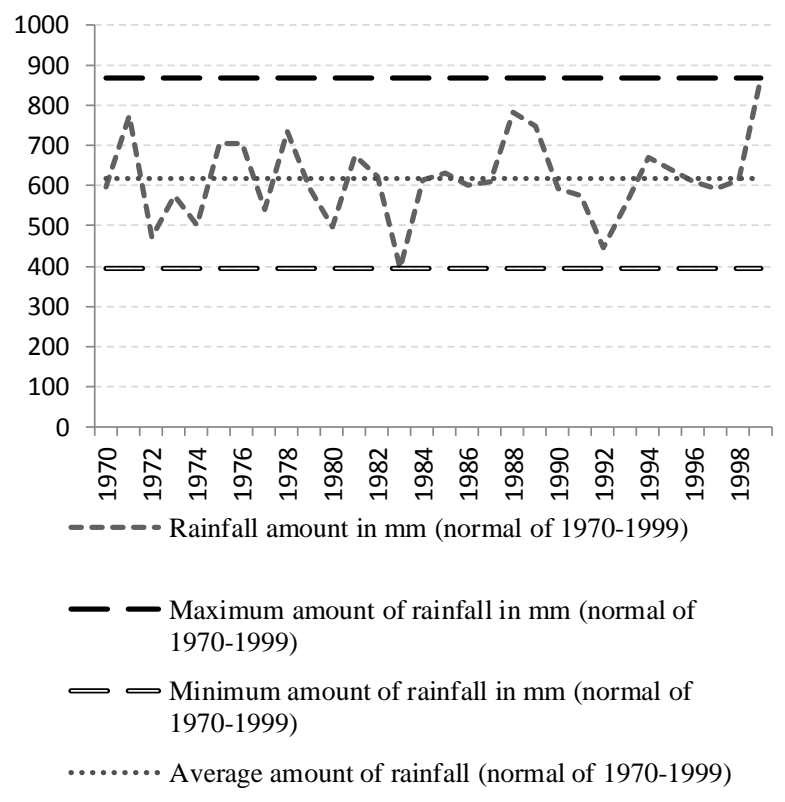

Source: République du Sénégal (2000).

In Senegal, from 1970 to 1999 (Fig. 2), rainfall is especially erratic, characterized by years of sharp decline in rainfall, contrasting with rainy years. During the years 1983, only $394 \mathrm{~mm}$ was recorded, the lowest rainfall amount for Senegal. By contrast, 1999 was a rainy period 
with the highest amount of rain. Although agricultural activities are mainly rain-fed, rainfalls seems to be very erratic.

In Senegal, during the critical decade of the 1980s, agricultural value-added has changed in the same direction as rainfall patterns (Figure 3). Moreover, the pattern of GDP growth seems similar to that of agricultural value added and this suggests that the behaviour of the rest of the economy is closely linked to agricultural performance, as highlighted by the intersectoral linkages and technical coefficients in the Senegalese input-output table. By the end of the period, it appears that better rainfall pattern goes with better growth path suggesting that a part of the recent growth renewal comes from better climatic conditions.

Figure 3: Evolution of the GDP growth, agricultural growth and changes in rainfall (in percent), 1980-1999

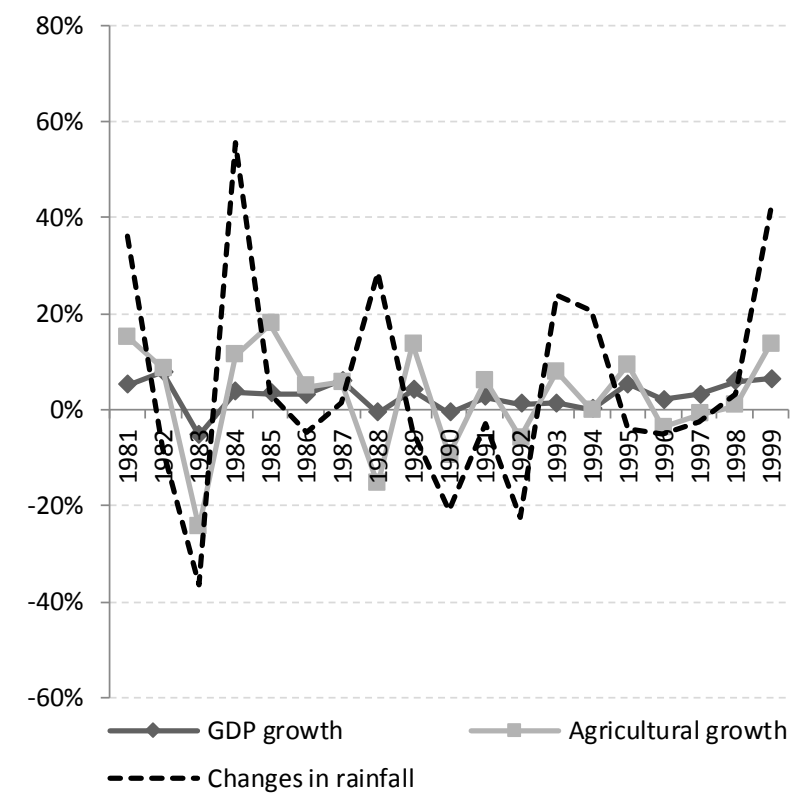

Source: République du Sénégal (2000; 2010)

\section{DATA AND METHODS}

In this paper, a dynamic general equilibrium model based on a 2005 social accounting matrix (SAM) of the Senegalese economy is used to trace the growth effects of rainfall fluctuations. In other words, this model uses a SAM from 2005 to simulate the effects of heavy and low rainfall patterns on growth.

\section{Model Description}

The dynamic model of the Senegalese economy used in this paper has been developed from the Exter model (Decaluwe, Martens, Savard, 2001). This model applies to a small open economy for which world prices are given. The model is designed as a set of simultaneous linear and non-linear equations, which define economic agents' behaviour, as well as the economic environment in which these agents operate. This environment is represented by market equilibrium conditions and macroeconomic balances. As rainfall shocks can induce wide effects in the long term, a dynamic recursive model is used.

A number of features have been added to the Exter model: i) an endogenous function of total factor productivity, the inclusion of public capital, land factors and dynamic updating equations. The model developed belongs to the strand of dynamic recursive CGE literature, which implies that agents' behaviour is based on adaptive projections rather than on the forwardlooking projections that underlie alternative intertemporal optimization models. Since a recursive model is treated one period at a time, it is possible to separate the within-period component from the between-period component, where the latter dictates the model's dynamics. In the next sections, we present an overview of the model's structure.

\section{The within period' component}

The within period component describes a one-period static CGE model. The model integrates six factors of production: non-qualified labour, qualified labour, private agricultural capital, private non-agricultural capital, public capital and land. The institutions selected are households in Dakar, households in other urban centres, rural firms, the state and the rest of the world. The added value of the agricultural sector is expressed as a Constant Elasticity Substitution (CES) function of composite capital and a composite factor aggregating land and labour, where labour is specified as a CES function of qualified and unqualified labour, while the composite capital is expressed as a Leontief function specifying fixed shares of public and private capital (private agricultural capital, private non-agricultural capital). The added value of the non-agricultural sector is instead expressed as a CES function of labour and nonagricultural capital. Moreover, a function of export demand in finite elasticity is introduced to take into account the constraints faced by Senegalese producers on the world market.

\section{The between period component}

While the static model described above is detailed in its representation of the Senegalese economy within a particular time-period, its inability to account for secondperiod considerations limits its assessment of the full effect of policy and non-policy changes. In order to take into account the dynamics underlying the impact of rainfall changes, such as the inter-temporal changes in investments and the rate of capital accumulation, the static model is therefore extended to a recursive dynamic model in which selected parameters are updated based on results from previous periods and inter-temporal behaviours. The introduction of dynamic updating equations contributes to better explain the linkages between rainfall changes, factor accumulation, and productivity changes. Current economic conditions, such as availability of capital are endogenously influenced by past economic conditions, but remain unaffected by forward-looking expectations. The dynamic model is also exogenously updated to reflect demographic changes that are based on observed or inferred projected trends. The 
process of capital accumulation is endogenous. The difference between the economic pattern under rainfall shocks and the counterfactual scenario (steady, average rainfall) are interpreted as the economy-wide impact of climatic events.

\section{Specific features}

The stock of sectoral private capital at period $\mathrm{t}$ is equal to the stock in the previous period, $\mathrm{t}-1$, minus capital depreciation, plus the capital accumulated during the period t. Private capital accumulated during a period depends on the ratio between return on capital and the cost of this factor. Agricultural private capital is distinguished from non-agricultural private capital as the first one goes specifically to rural households whereas the latter is supposed to be received by all categories of households. For a given sector $\mathrm{j}$, the stock of public capital at the period $t$ is also equal to the stock of the previous period $\mathrm{t}-1$ minus capital depreciation, plus the volume of investment accumulated during the period $t$. Public investment is a complement of private investment. This relation defines the one that links the public capital and the private capital in the tradable sector. In the public sector, the investment at period $\mathrm{t}$ depends on the available Government income.

The rainfall volume pluv tra for each period $t$ is a function of the benchmark quantity of rainfall pluvo and the index of rainfall tpluv in that area:

$$
p l u v_{\text {tra }}^{t}=\text { pluvo } * t p l u v^{t}
$$

The average volume is calculated over a period of 30 years (from 1970 to 1999), which captures the most important rainfall fluctuations in Senegal. The rainfall index tpluv is set as the ratio between the current rainfall volume and its average volume. Its calculation is inspired by the Palmer drought severity index (Palmer, 1965). It has been computed based on the data of Agricultural Ministry (République du Sénégal, 2000).

The total factor productivity (TFP) in agricultural sectors $\left(A_{t r a}^{t}\right)$ at period $\mathrm{t}$ is a function of the rainfall quantity. It increases with the latter, but it can also decrease when there is an excess quantity of rainfall. If the relation is firstly positive, it can be negative if the recorded quantity of rainfall is too important. For instance, flood is supposed to have an adverse effect on crops. So the correlation between the TFP and rainfall is positive can be inverted beyond a threshold. To better represent this relation, we assume that the TFP is as a quadratic function of the rainfall:

$$
A_{t r a}^{t}=h_{t r a}^{1} *\left(p l u v_{t r a}^{t}\right)^{2}+h_{t r a}^{2} *\left(p l u v_{t r a}^{t}\right)
$$

In the land market, there is a share $\left(\right.$ beta $\left._{-} l_{t}\right)$ of total land $\left(T O T L A N D_{t}\right)$ that is used. With a rise in rainfall, this amount of land used tends to increase. Drop in rainfall tends to decrease the quantity of land used. We assume that the amount of land used ( beta $_{-} l_{t}$ ) is positively correlated to the rainfall index $\left(t p l u v_{t}^{t}\right)$. According to the World Bank's estimates (2007), the unemployment rate for Senegal is $13 \%$ in Senegal (Eq. $3)$.

$b e t a_{-} l_{t}=b e t a_{-} l_{0} * t p l u v_{t}^{\alpha}$

Therefore, the rate of underused land is an inverse of beta $l_{t}$. Drop in rainfall tends to increase the quantity of land used. With a rise in rainfall, the amount of underused land tends to decrease.

Hence, supply of agricultural land is equal to the sum of demand of agricultural land by type, plus a volume of underused land. The Eq. 4 is inspired based by the one of unemployment in the labour market.

$$
\text { TOTLAND }=\sum_{\text {tra }} L_{A N D_{\text {tra }}^{t}+\left(1 / \text { beta }_{-} l\right) * T O T L A N D}
$$

Land market equilibria is, hence, supposed to be affected by rainfall hazards. In Senegal, following the last land census (République du Sénégal, 1996), just $60 \%$ of the agricultural land factor is used.

One feature of this model is the segmentation of labour market and the introduction of an endogenous unemployment. The wage curve approach, developed by Blanchflower and Oswald (1994), is used to model the labour market where we assume the existence of unemployment in the skilled labour market. Workers in this market are traditionally used in modern or formal sectors where there is a rigidity in the wage setting. The wage rate will therefore evolve according to the status of this labour market and this behaviour is described by the wage curve. It shows a negative relationship between levels of unemployment and wages but reflects the fact that areas (or sectors) characterized by high unemployment rates are associated with low wages while in area with low unemployment, high levels of wages are observed. In the unskilled labour market, workers are generally in the informal sector. The wage rate is assumed to be determined by the interplay of supply and demand. Thus, in this market, wage rate will be resulting on a balance between the supply and demand of unskilled labour.

\section{System Constraints and Macroeconomic Closures}

Equilibrium in the goods market requires that demand for commodities equals supply. Aggregate demand for each commodity includes household and government consumption spending, investment spending, and export and demand for transaction services. Supply includes both domestic production and commodity imports. Equilibrium is attained through the endogenous interaction of domestic and foreign prices, as well as the effects of shift that relative prices have on sectorial production and employment (and hence institutional income and demand).

Balancing factor demand and supply is based on factor market characteristics. Labour and land market are specified above. Capital is fully used and sector-specific. The model includes three broad macroeconomic accounts: the current account, the government balance, 
and the savings and investments account. In order to ensure equilibrium in the various macro accounts, it is necessary to specify a set of 'macro-closure' rules which provide a mechanism through which adjustment is assumed to take place.

The ratio between the current account and the GDP is assumed to be fixed overtime. This fits one of the convergence criteria of West African Economic and Monetary Union (WAEMU) which Senegal is subjected to. The exchange rate and inventories are fixed. Institutions' saving propensity is fixed. Public expenditures are assumed as fixed in real terms during the first period. However, they increase at the same rate as the population growth. Government savings, transfers, and labour supply follow the same pattern. Therefore, these different variables are fixed during the first period.

Whereas Senegal cannot borrow without any limits mainly due to convergence criteria established by the WAEMU, the long-term savings-investment linkage is characterized by exogenous savings with no feedback response from investment behaviour. Therefore the model adopts a savings-driven closure. Finally, the exchange rate is chosen as the numeraire. The model is also homogenous of degree zero in prices, implying that doubling all prices does not alter the actual allocation of resources.

\section{Data}

A social accounting matrix (SAM) was constructed for Senegal in 2005 from an input-output table (IOT) and a household survey performed in the same year (National Statistics and Demography Agency, ANSD). Data on rainfall has been collected from the statistical office of the Ministry of Agriculture. The resulting SAM is used to feed the general equilibrium model described above.

In this SAM, households are identified on the basis of three categories: rural households, households in Dakar as well as households in other cities. Production activities described by the SAM include agriculture, groundnut oil industries, other agri-food industries, other (non agri-food) industries, tradable services and nontradable services. The agricultural sector is further disaggregated into nine sub-sectors: maize, millet/sorghum, rice, groundnut, cotton, horticulture, fruit, livestock, fishing, and the rest of agriculture. Five of them (maize, millet/sorghum, groundnut, cotton, and "other agricultural type") are rain-fed. Rice, horticulture and fruit are mainly irrigated. We thus identify 15 production sectors in the national economy. With the lack of estimated elasticities for the Senegalese economy, the choice of some elasticities rely on some surveys done on some other developing economies. Income elasticities and the Frisch parameter come from work conducted by Dorosh (1996) on the economy of Madagascar and Dorosh and Lundberg (1993) on the economy of The Gambia. The elasticities of substitution and transformation come from the GTAP data basis and are the one for sub-Saharan Africa.

We simulate two main scenarios: an optimistic one and a pessimistic one. The scenarios rely on the observation of the rainfall trend during a period of three decades (1970-1999) characterized by extreme rainfall fluctuations in Senegal. During those three decade, years of drought like those of 1983 and 1980 — where recorded rainfall quantities were respectively $394 \mathrm{~mm}$ and 496 are in contrast with abundant rainfall years like 1999, when Senegal recorded $868 \mathrm{~mm}$. According to experts in hydrology, with a decline of $20 \%$ of rainfall, drought sets in Alberger, Carbonnel, Grouzis (1985). We assume that the business as usual (BAU) is given by the average rainfall recorded during the three decades $70 \mathrm{~s}, 80 \mathrm{~s}$ and $90 \mathrm{~s}$ is equal to $618 \mathrm{~mm}$. Hence, we simulate a pessimistic scenario of drought assuming a decrease of rainfall by $20 \%$ beyond the average rainfall of the decade of the 80 's. In the optimistic scenario, we suppose, by symmetry, an increase of rainfall by $20 \%$ below the average. The effects of those fluctuations on sectors, factors and GDP growth are analysed in the next subsections. We thus assume that the effects of changes in rainfall on sectors, factors and economic growth will pass through the channels of yields, availability of cultivated land and labour market. Even it's an important phenomenon; we do not analyse the issue of flood in this paper. The main channels of rainfall fluctuations effects on economic growth are productivity and returns. The indirect effect is related to changes induced by spillover effects of rain-fed agriculture on the rest of the economy. The agricultural sector is inter-linked with other sectors of the economy, as per the input-output matrix. In addition, a decline in rainfall will indirectly affect nonagricultural sectors depending on the intensity of the inter-relations they have with the agricultural sector. Any negative shock particularly on the "groundnuts" subsector in Senegal will have negative effects on the industrial sector (specifically the food oil industry). It will also affect key services along agri-food chains, such as transportation.

\section{Sectoral effects}

In the optimistic scenario, due to a high index of rainfall, the agricultural value added increases. Changes in agricultural value added with respect to the baseline are $8.6 \%$ in the first period and $14 \%$ in the last period (Figure 4a). Even if its changes are relatively low, tradable services are also sensitive to rainfall hazards, while the changes in non-tradables services are very low.

In the pessimistic scenario, one can observe the same range of decrease between sectors. Agricultural value added observes a drop from $9.3 \%$ in the first period to $16.9 \%$ in the last period. Apart from factor demand, agricultural value added is also driven by the TFP (Figure 4b). Due to inter-sectoral links, industry reacts to changes in agricultural value added induced by rainfall events. Food industries (including groundnut oil industry) predominantly influences that result.

\section{Impact on the returns on factors of production}

The agricultural sector makes intensive use of nonqualified labour. Agricultural capital and public capital used for agriculture are mostly used by groundnut, millet/sorghum and other type of agricultural sub-sectors. The agricultural capital is specific to the agricultural sector and it is mainly concentrated in the groundnut, millet/sorghum and other agricultural sub-sectors. Non- 
tradable services and industries mostly use qualified labour. Tradable services and industries use also the largest share of private and public capital.

Factors demand and returns will depend on sectors' technology and their reactions to rainfall fluctuations. The analysis of sectoral effects suggests that sharp reductions in rainfalls (pessimistic scenario) leads to lesser demand for land (and a decreasing return to land) during the period. Important increases in rainfalls (optimistic scenario) leads to an increase in the rate of returns to land due to an increasing demand for that factor (Figure 5).

During the periods of sharp increase in rainfall, rate of return on agricultural capital tends to increase due to an increase in the demand of that factor to offset the declining trend of productivity. By contrast, periods of sharp decline in rainfall are characterized by a decrease in returns to agricultural capital. However, rate of return to non-agricultural capital increases during periods of increase in rainfall, but at a decreasing rate. For both types of capital, changes from BAU tend to be reduced by the end of the period due to resource reallocation induced by the effects of long-term factor mobility (Figure 6).

During the periods of extreme increases in rainfall, wage rate for non-qualified labour tend to increase (optimistic scenario) (Figure 7). In the case of extreme decreases in rainfall, the demand for non-qualified labour tends to decreases in rain-fed agricultural sectors (pessimistic scenario). Non-agricultural sectors that are directly linked to agriculture tend to fall into recession and also released non-skilled labour. The wage rate for qualified labour tends to increase in periods of rainfall extreme drops - while it decreases in periods of sharp rise of rainfall (Figure 7).

Figure 4a: Changes in value added growth w. r. t. the baseline during the optimistic scenario (in \%)

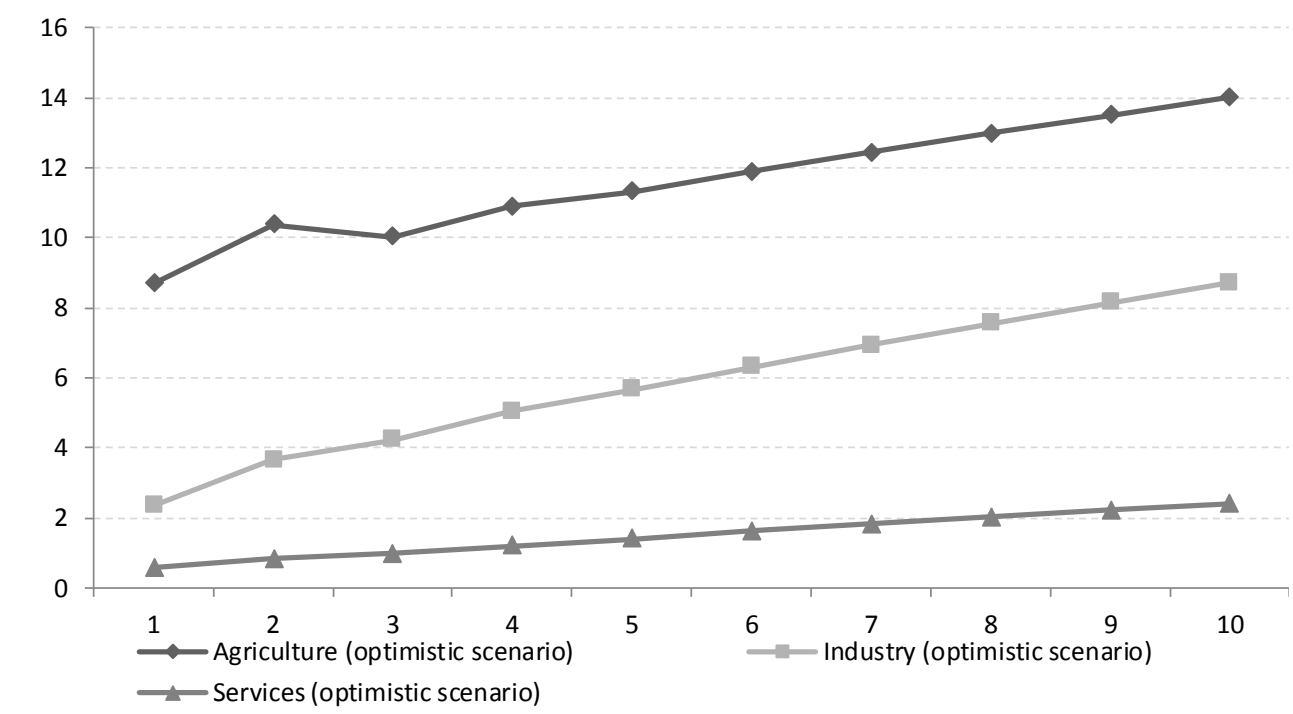

Sources: simulations

Figure 4b: Changes in value added growth w. r. t. the baseline during the pessimistic scenario (in \%)

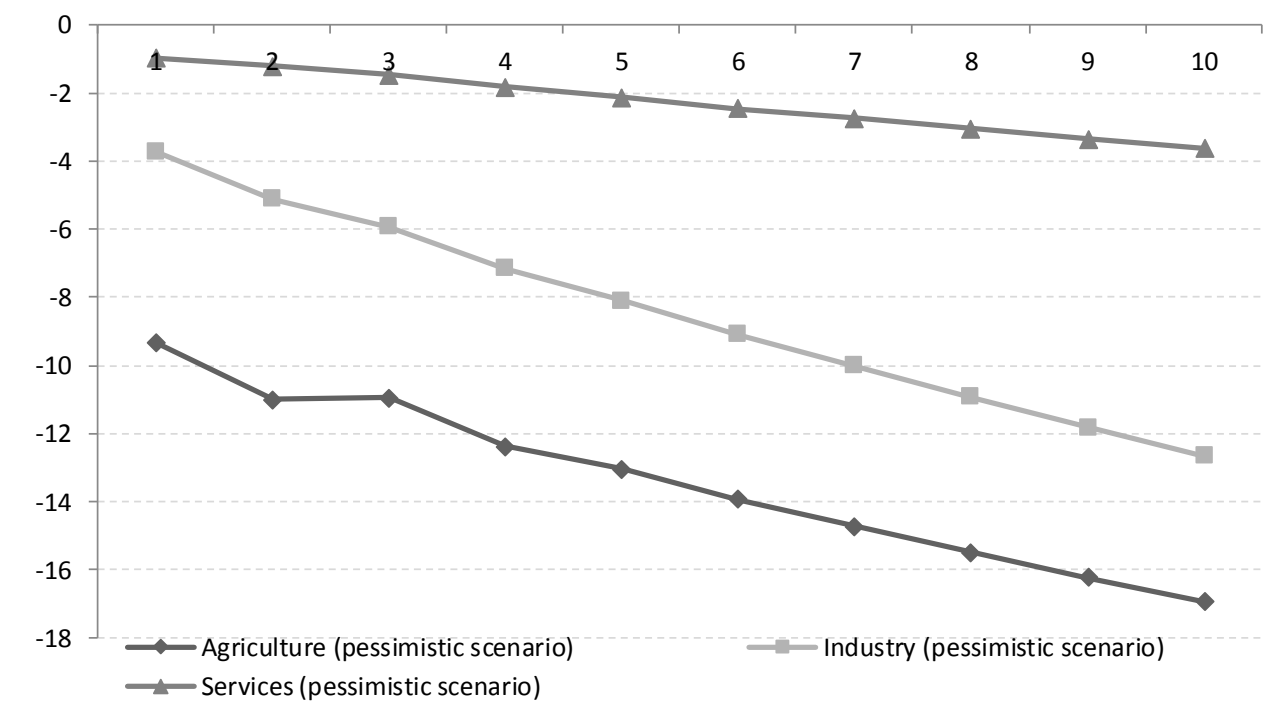

Sources: simulations 
Figure 5: Changes in the return to land (in \%)

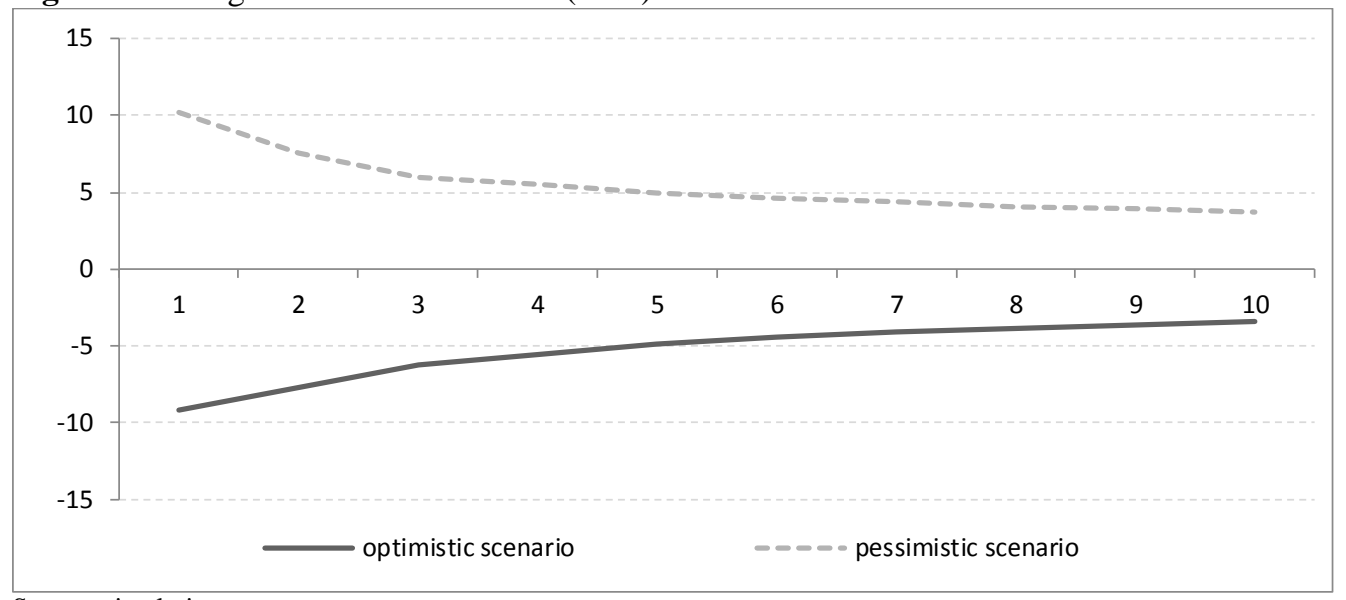

Source: simulations.

Figure 6: Changes in return to agricultural and non-agricultural capital (in \%)

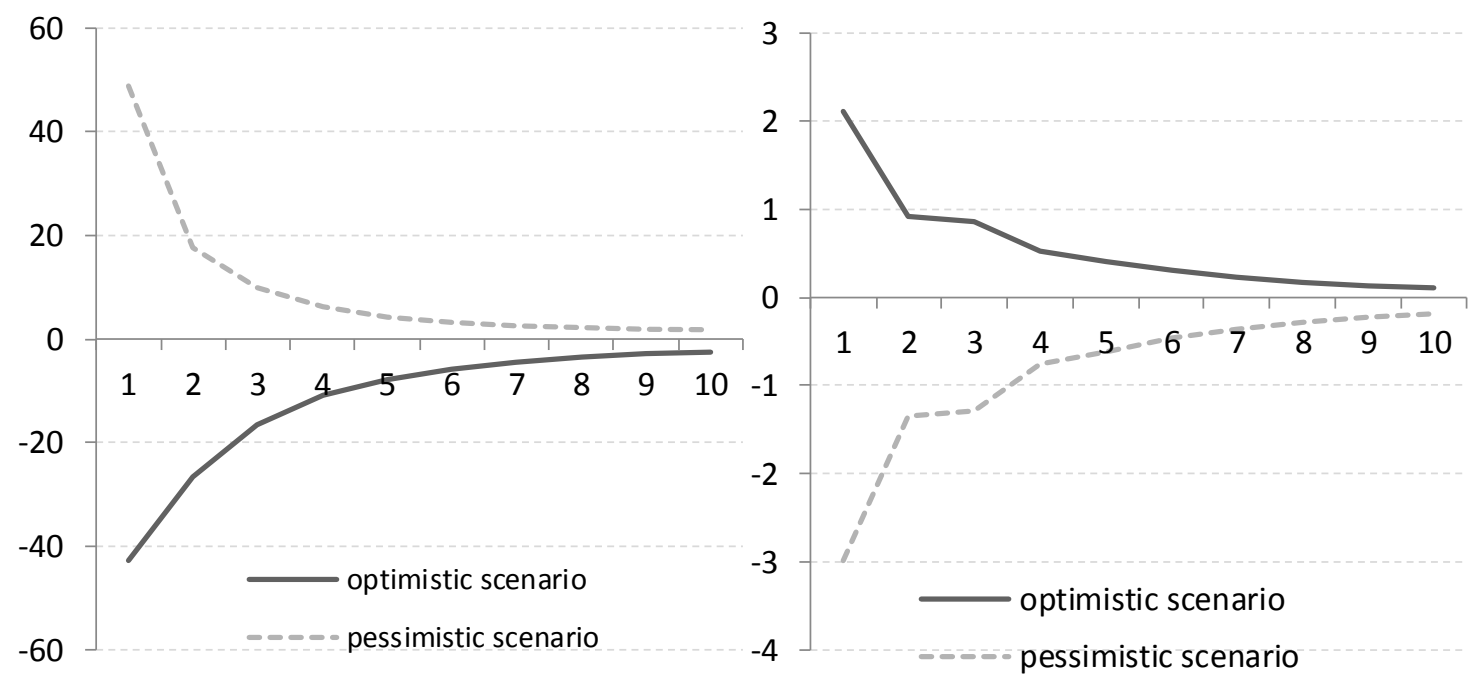

Source: simulations.

Figure 7: Changes in non-qualified and qualified wage rate (in \%)
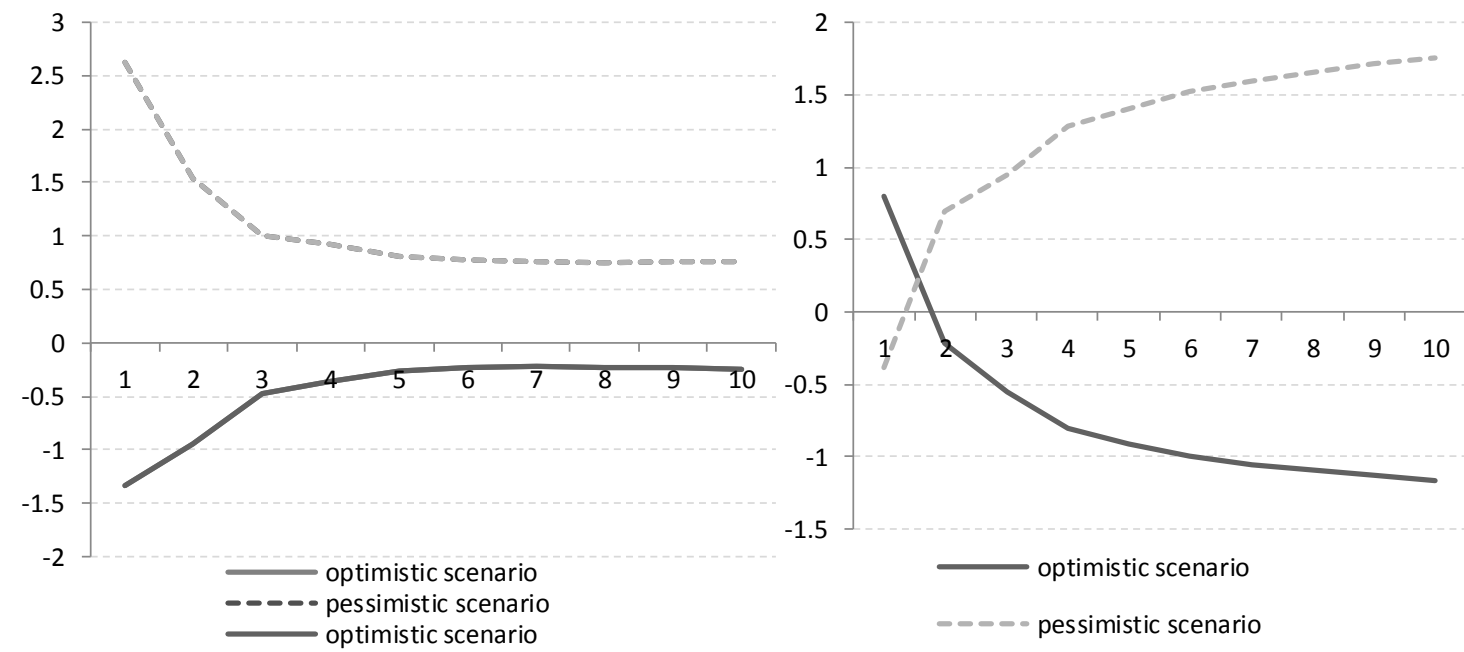

Sources: simulations. 
These dynamics in remuneration factors affect GDP trend.

\section{Impact on GDP}

During periods characterized by sharp rainfall increases (optimistic scenario), changes in GDP growth with respect to the baseline recorded progress from $2.3 \%$ in the first period to $5.7 \%$ in the last period (Figure 8). By contrast, during periods of sharp decline in rainfall (pessimistic scenario), changes in GDP growth with respect to the baseline shift from $-3.0 \%$ in the first period to $-7.8 \%$ in the last period. By comparing effects driven by optimistic and pessimistic rainfall pattern, it appears that in Senegal, extreme drops in rainfall tend to induce (in the long term) deeper reduction in GDP growth, than the one recorded during extreme rises in rainfall. As a result, sharp rainfall drops have a greater influence in loss of points in GDP growth, in proportion to GDP points gains in times of rainfall surplus. Losses of GDP during poor rainfall periods are greater in absolute terms than the gains during good rainfall periods, due to decreasing value added that is more proportionate than in the optimistic scenario. However, during periods of pessimistic scenario where the TFP decreases, there is a pressure on factors demand which set the rate of return relatively too high, to allow a significant increase of factors and value added. With regards to the two factors which are labour and non-agricultural capital that are the mainly used in the economy ( $81 \%$ of the factor return distributed in the economy), it appears that for a scenario of excess rainfall, demand for labour increases by 1.9 points of percentage (by4.8 points of percentage for nonagricultural capital) at the end of the period. Also, it decreases by 2.9 points of percentage (by 6.9 points of percentage for non-agricultural capital) for a scenario of rainfall shortage. This result comes from the fact that during optimistic scenario, producers tend to demand less factors due to an increase in productivity.

Figure 8: Changes in GDP growth w. r. t. the baseline (in \%)

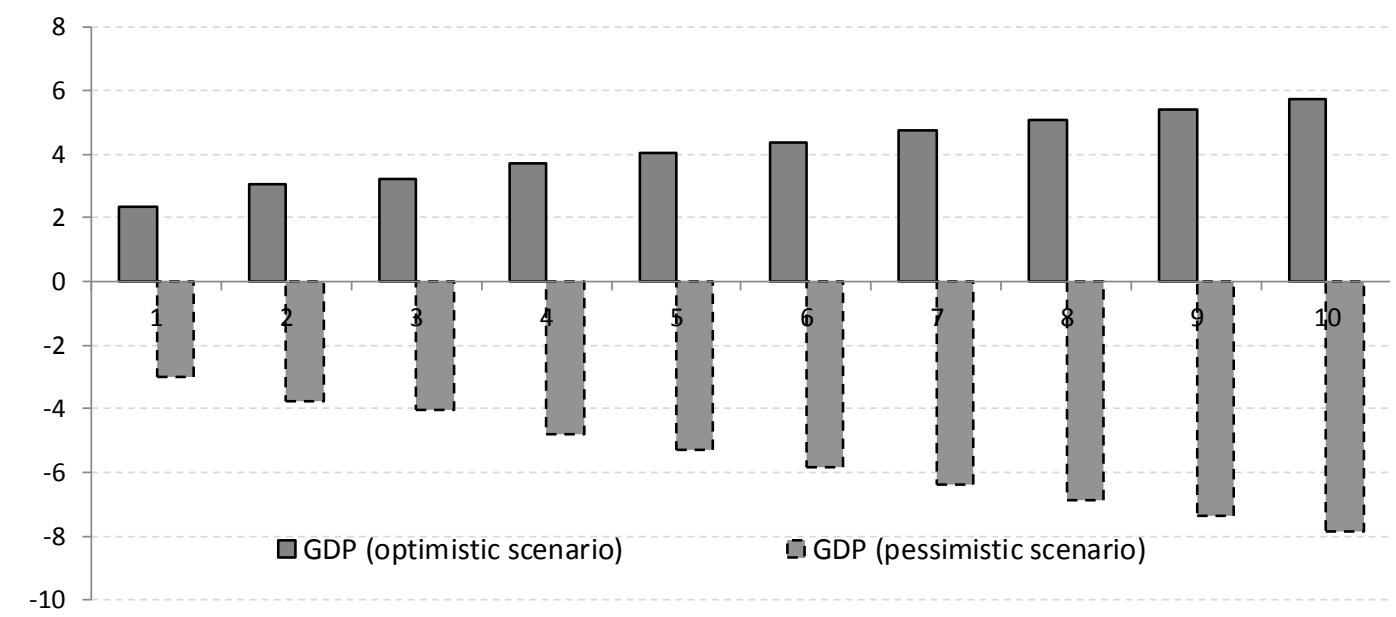

Sources: simulations

\section{CONCLUSION AND POLICY LESSONS}

Senegal is a Sahelian country where agriculture is largely dependent on rainfalls. In this paper, we first build a general equilibrium dynamic model within which we introduce an index that captures rainfall fluctuations and link it to the total factor productivity and the factors market. We then simulate and evaluate effects of extreme events in rainfall pattern on sectors, factors remuneration and GDP in Senegal, by assuming an optimistic and a pessimistic scenario. In the optimistic scenario, we assume a rainfall increase by $20 \%$ beyond the average rainfall of the $70 \mathrm{~s}, 80 \mathrm{~s}$ and $90 \mathrm{~s}$. In the pessimistic scenario, we suppose also a decrease of rainfall by $20 \%$ below the average.

The results obtained show that sharp drops in rainfall lead to negative effects on GDP, while periods of abundant rainfalls have a positive effect on GDP. However, losses in GDP growth induced by sharp rainfall drops are more proportional than gains in GDP growth recorded during periods of abundant rainfall. Whatever could be the amount of resources devoted to boost economic growth, this seems to be very sensitive to rainfall shocks in Senegal as drops in rainfall lead to a reduced economic activity or recessions.

Therefore, water management is going to become highly crucial over the future for issues related to economic growth in Senegal. This is specifically a challenge for Senegal given that the country has mostly rural dry-lands. As a result, better management of ground water basins, renovation of dried natural water ponds and extension of irrigated land will be key pillars that will help the country to reduce agricultural sector dependency on climate change.

\section{REFERENCES}

ACEMOGLU, D., AGHION, P.H. and ZILIBOTTI, F. (2006), Distance to frontier, selection and economic growth, Journal of the European Economic Association, 
4(1):37-74, DOI: 10.1162/jeea.2006.4.1.37

AGHION, P.H. and HOWITT, P. (1992). A model of growth through creative destruction, Econometrica, 60-2, pp. 323-351.

ALBERGER J., CARBONNEL J. P. and GROUZIS M. (1985). Sécheresse au Sahel: incidences sur les ressources en eau et les productions végétales. Veille climatique satellitaire, no. 7 (18-30)

BARRIOS S., B. OUATTARA and E. STROBL (2008). The impact of climatic change on agricultural production: Is it different for Africa? Food policy, Volume 33, Issue 4, pp. 287-298. doi: https://doi.org/10.1016/j.foodpol.2008.01.003

BARRIOS S., BERTINELLI, L. and STROBL, E. (2010), Trends in Rainfall and Economic Growth in Africa: A Neglected Cause of the African Growth Tragedy. The review of economics and statistics, Vol. 92, No. 2, Pages 350-366. doi: 10.1162/rest.2010.11212

BARRO R. and SALA-I-MARTIN X. (1995), La croissance économique, McGraw Hill

BLANCHFLOWER, D. G \& OSWALD, A.J. (1994). Estimating a wage curve for Britain: 1973-90, Economic, Journal, Royal Economic Society, vol. 104 (426), pp. 1025-43. doi: 10.3386/w4770

BENSON, C. (1994). Drought and macroeconomic performance: a comparative analysis of six sub-saharan African economies, mimeo. London: Overseas development institute.

BLOOM, D. E., SACHS, J.D., COLLIER, P. and UDRY, C. (1998), Geography, demography and economic growth in Africa. Brooking papers on economic activity, vol. 1998, no. 2, 207-295. doi: $10.2307 / 2534695$

BOCCANFUSO, D., CABRAL, F., CISSE, F., DIAGNE, A. and SAVARD, L. (2007), Stratégies de réduction de la pauvreté au Sénégal: une analyse par la modélisation en équilibre général calculable microsimulé, L'Actualité Economique, vol. 83, no. 4;

BOCCANFUSO, D., CABRAL, F.J. and SAVARD, L. (2005). An analysis of the impact of liberalization of the groundnut sector in Senegal: a general equilibrium model multi-household, Africa Perspective, Vol. 1, No. 1, pp. 32-58.

COLLIER, P. and GUNNING, J. W. (1999a). Why has Africa grown slowly? Journal of economic perspective, vol. 13 , no. 3

COLLIER, P. and GUNNING, J. W. (1999b). Explaining African economic performance, Journal of economic literature, 37: 64-111

CABRAL F. J. (2004). Accord agricole et redistribution des revenus au Sénégal : essai de simulation à l'aide d'un modèle d'équilibre général calculable, Thèse de doctorat, Université Cheikh Anta Diop de Dakar.

DECALUWE B., MARTENS A. \& SAVARD L. (2001). $\mathrm{La}$ politique économique du développement et les modèles d'équilibre général calculable, Presse de l'Université de Montréal, AUPELF/UREF,

DIAGNE, A., CABRAL, F.J., CISSÉ, F., DANSOKHO, M. and BA, S. (2008), Trade policies, regional integration,poverty and income distribution in Senegal, in Trade liberalization and poverty: a CGE analysis of the1990s experience in Africa and Asia, Cockburn, J., B. Decaluwé and Veronique Robichaud, eds., PEP.

DISSOU, Y. (2002). Dynamic effects in Senegal of regional trade agreements among UEMOA countries. Review of international economics. Volume 10, Issue 1, February 2002, p. 177-199. doi: 10.1111/14679396.00326

DOROSH, P. (1996). Structural adjustment, growth and poverty in Madagascar: a CGE Analysis, monograph no. 17, NY: Ithaca. Cornell University Press

DOROSH, P. and LUNDBERG, B. (1993). Aids flows and policy reform: a general equilibrium analysis of adjustment and the poor in the Gambia. Working Paper 46, NY: Ithaca, Cornell Food and Nutrition Policy Program.

DUMONT J .C. et MESPLE-SOMPS S. (2001), Des retombées généralement bien appréciées : infrastructure publique, croissance et compétitivité au Sénégal, In La politique économique du développement et les modèles d'équilibre général calculable. Montréal: Presse de l'Université de Montréal, AUPELF/UREF.

FOFANA, I., COCKBURN, J., DECALUWE, B., DIAGNE, A., CABRAL, F. J. and CISSE, F. (2006), Libéralisation commerciale et pauvreté en Afrique: le cas du Sénégal, Banque mondiale/Cirpée/Ulaval ;

GIEC (2007), La fonte des glaces de l'Himalaya est virtuellement sûre d'augmenter les inondations, les chutes de rochers se décrochant des pentes et la perturbation des ressources en eau, OMM/PNUE

JURY, M. R. (2002). Economic impacts of climate variability in South Africa and development of resource prediction model, Journal of applied meteorology, vol. 41 pp. 46-55. https://doi.org/10.1175/15200450(2002)041<0046:EIOCVI>2.0.CO;2

MANKIW N. G., ROMER D. and WEIL D. (1992). A contribution to the empirics of economic growth. Quarterly Journal of Economics, 107-2, pp. 407-436. DOI:https://doi.org/10.2307/2118477

McDOUGALL, R. (1997), Global Trade Assistance and Protection: The GTAP 3 Data Base, Center for Global Trade Analysis. Purdue University, West Lafayette, Indiana

NICHOLSON, S. E., (1994). Recent rainfall fluctuations in Africa and their relationship to past conditions over the continent, The Holocene, 4: 121-131.

NELL, K. (2003). Long run exogeneity between saving and investment: evidence from South Africa, Working paper 2, Johannesburg, South Africa: Trade and industrial policy strategies.

O'CONNELL, S. A. and NDULU, B. J. (2000). Africa's growth experience, mimeo

PALMER, W.C. (1965). Meteorological drought. Research Paper No. 45, U.S. Department of Commerce Weather Bureau, Washington, D.C.

PARRY, M.L., DUINKER, P.N., MORISON, J.I.L., PORTER, J.H., REILLY, J. and WRIGHT, L.J. (1990), Agriculture and forestry. In: Climate Change: The IPCC Impacts Assessment. Tegart, W.J., Sheldon, G.W. and D.C. Griffiths.

RÉPUBLIQUE DU SÉNÉGAL (2000). Statistiques agricoles, Ministère de l'Agriculture.

RÉPUBLIQUE DU SÉNÉGAL (2010), Analyse des comptes nationaux $\mathrm{du}$ Sénégal, 
http://www.ansd.sn/publications annuelles.html REPUBLIQUE DU SENEGAL (1996), Plan d'action foncier, Ministère de l'Agriculture.

STUART, R., BROWN, S. AND HANSLOW, K. (1997), The Megabare model and climate change policy, the role of research in policy development. AIC conferences, government policy conference Sydney, 4-5 August 1997.

TALHULE A. A. (2007). Climate information for development: an integrated dissemination model, Africa development, Vol. XXXII, no. 4, pp. 127-138. http://dx.doi.org/10.4314/ad.v32i4.57325

UNITED NATIONS STATISTICS DIVISION (2006), Rainfall variability and economic growth in Zimbabwe, UN Common Database - GDP annual rate of growth (World Bank estimates). http://unstats.un.org/unsd/cdb/ (accessed September 27, 2006) Meteorological Services Department, Zimbabwe, 2006

WORLD BANK (1991). Food security and disasters in Africa: a framework for action. Africa technical department, Washington, DC: World Bank.

WORLD BANK (2000). Can Africa claim the 21th century? World Bank, African development bank, United Nations Economic Commission for Africa.

WORLD BANK (2012a). Global economic prospects 2012.

WORLD BANK (2012b). World Development Indicators.

HRESH, J. M., OWUSU, G. L. K., \& OLLENNU, L. A. A. (1988). Cocoa swollen shoot: an archetypal crowd disease. Zeitschrift für Pflanzenkrankheiten und Pflanzenschutz, 95(4): 428-446. URL: http://www.jstor.org/stable/43383326

TIEDEMANN, T. AND LATACZ-LOHMANN, W. (2012). Production risk and technical efficiency in organic and conventional agriculture - The case of arable farms in Germany. Journal of Agricultural Economics DOI: 10.1111/j.1477-9552.2012.00364.X.
TZOUVELEKAS, V., PANTZIOS, C. J. AND FOTOPOULOS, C. (2001). Economic efficiency in organic farming: Evidence from cotton farms in Viotia, Greece. Journal of Agricultural and Applied Economics, 33: 35-48.

DOI: $10.1017 / \mathrm{S} 1074070800020769$

TZOUVELEKAS, V., PANTZIOS, C. J., \& FOTOPOULUS, C. (2002a). Technical efficiency of alternative farming systems: the case of Greek organic and conventional olive-growing farms. Food Policy, 26 (6): 549-69. DOI: http://dx.doi.org/10.1016/S03069192(01)00007-0

TZOUVELEKAS, V., PANTZIOS, C. J., \& FOTOPOULOS, C. (2002b). Empirical evidence of technical efficiency levels in Greek organic and conventional farms. Agricultural Economics Review, 3(2): 49-60.

UNDP (1992): Benefits of diversity: An incentive towards sustainable agriculture. United Nations Development Programme, New York.

UNESCO (2016). UNESCO Institute for Statistics database. Available at:

http://data.uis.unesco.org/Index.aspx?queryid=166

Accessed July 6, 2016.

WHO (2003). WHO definition of Health. Accessed on April, $\quad 2012$ 2, Available at: http://www.who.int/about/definition/en/print.html. YGL (2013). Information available from Yayra Glover Limited. http://yayraglover.com/ 